\title{
ENGAGING STUDENTS IN READING BY ANALYZING CHARACTERS AS A PART OF EXTENSIVE READING ACTIVITY
}

\author{
Eros Meilina Sofa \\ Institut Agama Islam Negeri Pekalongan, Indonesia
}

\begin{abstract}
This article discusses about character analysis of a story as a part of Extensive Reading to engage students in reading activity. The writer used qualitative approach to conduct this research by analyzing their works and arguments after the task given, and there were 95 students of English Education Department as the participants. In order to get the data, there were two main sources, the students' analysis and their written comments on the work. To maintain the concept of Extensive Reading, the students had to read the story and gave their analysis freely on a paper. They also had to write their comment toward the story in several sentences. The result revealed that students could express their ideas and creativity on the paper as well as their capability in creating English sentences. Besides, they could increase their self-confidence because of their ability in reading and analyzing the English story.
\end{abstract}

Key words: analyzing characters, story, extensive reading, creativity

\section{INTRODUCTION}

Reading is significant but complicated activities in learning process, especially in foreign language learning. Reader's focus and understanding on what he is reading provides him new or additional information to respond his curiosity, prove the use of reading activity, and avoid useless reading time as well as support the reader's interest in the field. The more interest and curiosity of the reader, the more information he will read and find to fulfill his satisfaction in gaining the information. Therefore, students need a stimulus and more motivation to increase their curiosity and need of their knowledge to increase their reading activity. In fact, asking questions orally to someone they trust is still their preference because of the simplicity rather than reading the trusted source.

Various text is able to accommodate readers from any source of field, especially students to choose what kind of text they want to read. Novels or short stories are the preference for them who like fiction texts, while those who love non-fiction textsread newspapers, magazines, social media platforms, etc. Both kinds of texts have benefits which support the readers to be more informed, critical, creative, and developed in different ways. This fact comes to the assumption that the various text is able to accommodate human's need in gaining more knowledge based on their interest and competence.

In English learning, there is Extensive Reading which isdifferent from Intensive reading but practically they are inseparable. Extensive reading is the reader's door to open their adventure and exploration they like in order to add any information which has been invisible in front of them. This type of reading can serve significant development in students' reading over time (Grabe and Stoller: 2002). Itholds Reading for Pleasure as its concept, creating comfortable 
atmosphere during the reading activity. It means that students of Education Department do not have to read texts related to educational field. Therefore, there is no limit in choosing the theme and genre.

In choosing text they want to read, most students prefer fiction texts rather than nonfiction texts, because fiction provides living things and able to engage students in reading activity. fictional stories are informative in thatthey allow for prediction and explanation while revealing theunderlying processes of what is being modeled (Mar and Oatley:2008). Because of this, teacher can maximize the potentials of fiction texts to motivate and encourage reading activities, because the more students read, the more information they get. As the result, teacher can guide the students to explore parts of fiction text deeply.

\section{LITERATURE REVIEW}

\section{Reading as the Main Tool of Learning.}

Reading is the main tool of learning any kind of field that it is impossible for everybody to get any information without reading anything. Reading can be defined as a process to understand the meaning of a written text (Richards and Schmidt, 2010). Reading comprehension is critical for long-term academic success anddependent on language abilities that emerge early inlife (David K. Dickinson, Julie A. Griffith, Roberta Michnick Golinkoff, and Kathy HirshPasek: 2012).

Unfortunately, reading culture is in low level in our society, even among college students although they know well the influence of reading for their achievement. Nessien (2008) emphasized that reading culture strongly support students' success in education and in the modern complex society. Today people prefer to read information through social media or electronic devices, even the use of the media has more significantly increased than paper based information.

In order to practice reading comprehension, readers must be able to read text fluently. Hudson, Mercer and Lane (2000) elaborated three elements of fluent reading, which are accurate reading of connected text at a conversational rate with appropriate expression, maintaining performance of reading fluently for long periods of time, and not easy distracting. Those three emphasize that reading will be no use when it is practiced in low motivated action.And in this technology-based era, when someone lose his motivation in reading information from social media, he will be left behind since people like to use social media to announce or inform anything rather than inform it orally to others.

In line with the concept, Grabe and Stoller (2002) elaborated seven main purposes of reading as stated as follows:
a. to search for simple information
b. to skim quickly
c. to learn from texts
d. to integrate information
e. to write
f. to critique texts
g. to achieve general comprehension 
Those seven purposes define reading as the source of information that must be a habit for students in gaining information.

\section{Extensive Reading is a Broad Field of Reading Activity}

Extensive reading is a technique in teaching reading which is defined as a situation where students read a lot of materials in their level in a new language; they read for general, for overall meaning, and for information at one with enjoyment (Day and Bamford, 2004). Extensive reading does not only put understanding and learning as the significant points in reading, but also students' pleasure and interest. Like Hedge, cited by Ferdila (2014), explained that the concept of extensive reading is exposing students to an input-rich and enjoyable environment, with the intention that their language knowledge will improve and their enthusiasm to learn will develop naturally.

In this activity, students are not demanded to fulfill teachers' expectation in understanding and answering questions based on the text since they can read what they want, and they can choose the topic that they are interested in. No exercises, no questions at the end of the chapter, and no looking up every word in a dictionary are required. "It is the kind of reading highly literate people do all the time" (Krashen: 2004).

Davis in Renandya (2007) offers a more useful definition of extensive reading from a classroom implementation perspective:

An extensive reading programme is a supplementary class library scheme, attached to an English course, in which pupils are given the time, encouragement, and materials to read pleasurably, at their own level, as many books as they can, without the pressures of testing or marks. Thus, pupils are competing only against themselves, and it is up to the teacher to provide the motivation and monitoring to ensure that the maximum number of books is being read in the time available. The watchwords are quantity and variety, rather than quality, so that books are selected for their attractiveness and relevance to the pupils' lives, rather than for literary merit.

Besides the concept of Reading for Pleasure, Extensive Reading guides the students to practice reading fast, that they can gain information in one time without opening their dictionary to understand vocabulary frequently. This activity produces students' habit in reading and their understanding in the context of the text they have read. According to ER foundation, there are four different levels in practicing Reading:
Reading Pain
: too hard, poor comprehension, high effort, de-motivating
Intensive Reading
Extensive Reading
: Instructional level, can learn new word and grammar
Speed reading practice
: fast, fluent, adequate comprehension, enjoyable
: very fast, fluent, high comprehension, natural reading, enjoyable

Extensive reading is a procedure where learners are supposed to read and comprehend large quantities of material or long texts in pleasure and interesting way. (Bamford, 2004). Therefore, to build the pleasure and enable the reading activity becomes easy and enjoyable, students should not open their dictionary too often. When they do that, it means their reading material is too hard for them (www.erfoundation.org).

Abedelqader and Salameh conducted a research about Reading English in Hail University in KSA (Kingdom of Saudi Arabia), participated by 70 undergraduate students and found that 
three attitudinal values were measured whichwere Affective, Cognitive and Behavioral. They were measured by 20-item questionnaire. The results indicated that even though the majority of the EFL learners didn't like reading inEnglish at the beginning of the semester, most of them responded positively towards extensive reading after fifteen weeks of extensive reading implementation inside and outside the class.

Bamford (2004) stated that reading enables students to improve their reading, writing, listening and speaking abilities as well as become better and more confident readers and enrich their vocabularies. Nishino (2007) reported that students' literacy level in English increased as a result of the positiveattitudes that they developed toward reading.

\section{Fiction and Character Analysis in Extensive Reading Activity}

Hallet stated that fiction is defined as any imaginative re-creation of life in prose narrative form. Fiction sometimes reflects the world by providing evidence of an incident or event that we may not have learned as we could have done. It can help us to reveal information that we have not obtain in the world (Lewis: 1978).

Garcia (2016) assumed a possible mechanism for how we can learn straightforward empirical truths from fictions, both about particular matters of fact and about universal truths. All fiction is a falsehood of sorts because it relates events that never actually happened to people (characters) who never existed, at least not in the manner portrayed in the stories (Hallet).

Related to fiction texts, character analysis is the process of evaluating the specific traits of a literary character, including consideration of additional elements such as the role in the story and the various conflicts the characters experience (www.aresearchguide.com/write-characteranalysis.html). By analyzing characters, students are able to improve their comprehension in reading stories and learn moral value from the protagonists.

An English education students, especially English text readers, they have to be able to draw similar conclusions about the actions of characters by paying close attention to information the author of a short story provides about the background, experiences, and personalities of the characters (Kennedy and Gioia). Moreover, the good analysis demonstrates the student's ability to identify the relationship between character and action in the story (http://facultyweb.wcjc.edu/users/jonl/documents/charanalysis.pdf).

\section{RESEARCH METHODOLOGY}

\section{Approach}

This study used qualitative approach to measure the students' ability in analyzing characters in fiction texts as well as their capability in arranging understandable sentences and expressing ideas.

\section{Participants}

Participants of this research were 95 students in the second semester of English Department of IAIN Pekalongan. They were divided into three classes, and each class had similar level in English Reading Comprehension. The students' capability could be seen from their Intensive Reading score in the previous semester. They had experienced techniques in reading which could be their modal in participating in this research.

\section{Data Collecting}


There were several steps to obtain the data and analyze the students' work. The steps are stated as follows:

\section{Introducing Extensive Reading}

In this first step, the lecturer explained the learning overview and introduced the essence of Extensive Reading. This explanation was important to enable students focus in reading activity. And in this step, most of the students did not like reading any text in English, especially in the form of long texts. Therefore, the lecturer had to explain that the focus of Extensive Reading was not only understand the text, but also made the reading become their habit.

\section{Distributing Reading Material}

The lecturer provided some different stories to facilitate the students in choosing appropriate title and story they like individually. Those stories were in different levels of length and difficulty, and there was no recommendation for the students to choose the longer or more difficult stories. Therefore, the students were able to challenge themselves in gaining more vocabulary and references, and come out of their comfort zone. It was allowed for the students to choose short and simple text, but it was not a problem because in Extensive Reading activity the reading material cannot be forced to the student.

\section{Limitation of the Reading and Analyzing Time}

There were two weeks long for the students to read and analyze the characters of the story. They were allowed to read more than one story, meaning they would get more information and knowledge from it. In two weeks, the students were guided to find anything and practice their critical thinking. However, in order to avoid choosing similar story among those students, a week after the assignment had been given, the lecturer asked the students individually which title they chose.

\section{Analyzing Character Process}

Students had to analyze characters in the story in detail and comprehensive explanation. The lecturer did not give too many rules in presenting their ideas on their work. They were only asked to represent their creativity on the work.

\section{RESULTS AND DISCUSSION}

\section{Students Enjoy Reading Novels, Even More than One Novel.}

From the 95 students participated in this research, only 10 students who had liked reading activity, and they had chosen texts or books written in Indonesian. However, after they learn Extensive Reading deeply, they started to like this activity. Even, 40 students told they started reading novel or short stories in English.

It was undeniable that the students initially read the novels because of the task. But the fact showed they started to read more than one stories and enjoyed what they were reading. Absolutely, the lecturer had to motivate the students in the beginning of the meetings, by convincing them about the use and enjoyment of reading activity. Like Bamford (2004) suggested that a teacher should persuade his students to love reading and do it as their habit, and 
it can be realized when the students meet comfort and pleasure while reading.By giving assignment using the story, students started their habit in reading English text. It appeared when there were some students read more than one story and this fact proved that Extensive Reading holds "Reading for Pleasure" concept.

It was undeniable that the various length and title of the stories took important role in supporting their Extensive Reading activity. Although initially most of them chose one short and simple story, this activity gradually provoked students to read longer stories and texts. Based on the students' argument, there were several reasons made the students familiar with reading habit, such as:

- reinforcement given by the lecture stating that their reading assignment influenced their final score in the semester

- their curiosity in finding new or more stories in English

- fun learning in enriching English vocabulary by reading those fiction texts

- Self-proving that reading English texts can be fun when they chose fiction texts, so they were able to change their own thought assuming that English texts are difficult to understand.

For some students, especially female students, reading novel could reflect their own life and represent their feelings. Most of them agreed to say that they lovedthe story in a novel because of the plot and the characterization performedtheir personality and someone they knew. Besides, the plot was like to retell or explain their feeling toward problemsfaced in the real world. Meera and Remya also presented this fact on their research, which mentioned reading can sharpen insight and sight, explore feelings and experiences and treats human to learn and face their problems in their life.They showed their feeling when the lecture asked them to discuss about the content of the story, as if were engaged in the story because of one moment of character in the story. This fact is in line with Hallet's definition of fiction text, stating that fiction reflects people's reality in the other way.

\section{Students like to expose their creativity in presenting their analysis}

Presenting ideas on papers in the form of drawing pictures and colorful objects were more interesting for the students rather than explaining the ideas in the form of writing long description of an essay. It could be seen from the students' work that most of them were in the form of picture-text combination. 70\% of the 95students' work were presented in picture-text combination, by providing the picture of the character names and short-sentences description as thecharacter traits beside the picture. Even, there was one of the students made some small cards, with a name of the characters and its personality on the each card, then stuck them on a thick colorful paper.

The students' work appearance represented what Safaeia and Bulca (2013) did in their research, which focused on students' creativity improvement in second language skills. Therefore, it was undeniable to say that Extensive Reading support students' creativity in presenting ideas and critical thinking toward the story they have read.

Besides the imaginative and colorful objects on the works, their creativity appeared on the sentences they made. Among those students in different level of English mastery, 50\% preferred to use short and simple sentences to elaborate their argument, especially in giving comment toward the content and characters of the story. $40 \%$ of them used long and repetitive sentences which looked as if they could have made long sentences properly, and $10 \%$ of the students could not elaborate their ideas well in giving comment so they only wrote very simple 
sentences containing a clause in representing their feeling. The length and quality of the sentences were actually influenced by their ability and habit in free reading, meaning that the more they practiced extensive reading, the more they were able to produce long and meaningful sentences. It was in line with Rankin (2005) who stated that extensive reading produce the improvement of second language acquisition. Absolutely by reading more text students are able to absorb more vocabulary and ways of delivering argument, then support their creativity in presenting comment. Like Nanda, Arti and Pal in Meera and Reyma, who stated that student's high creativity promotes better academic achievement.

In oral practice, not all students are active to show their creativity in presenting argument, and they do not have much time to think about what ideas they wanted to express, what sentences they will use, and how they could express it to be understood by others. Crystal in Sofa (2018) said that in spoken or oral communication, there are tones, stresses and intonation, but in written communication, there is a term of paralinguistic, which expresses feelings by using emoticons, colors, capitalizations, choice of words, or other features.

\section{Analyzing characters of a novel improve students' motivation in reading English text.}

By reading and analyzing characters in one story individually, each student could prove to him/herself and the others that he/she has capability in reading, understanding, and giving comment of the characters in an English text, although it was in the form of fiction text. The students got their self-confidence which provoked them to read more texts.

In this Extensive Reading activity, they were not demanded to focus on the grammar used in the analyzing the characters of the story. They could decide the time, setting, characters and characters' feeling by analyzing the sentences, then made them into their own conclusion. This activity supported their critical thinking and it was not only aboutreading a text, but also a challenge to analyze the sentences to understand the context as well as the vocabulary. They had to know the new terms or new expressions stated by one of the characters by using new vocabulary, but they could find it because of their curiosity and motivation to get the detail information in it. Like Connel (2012) believed thatan author does not prefer to mention the character traits directly in the story. Therefore, the reader has to find the personality by themselves by analyzing the character's actions and conversation.

The students' high curiosity and motivation could be seen from their comments in deciding their favorite character, which most of them mentioned several attitudesof the character although they found it was hard to try to find meaning of new vocabulary. Absolutely finding the meaning of new words would be more boring when they had to find the meaning in a classroom because the lecturer instructed them to do it.One for sure that it was not an easy work for the students to analyze the character in the story, because most of them were not in the high level of vocabulary mastery. Therefore, by choosing the story by themselves, they could measure their own level because researches suggested that "students should read a book a week or more at their ability level" (www.erfoundation.org).

\section{Students can achieve the benefits of Extensive Reading}

Based on the concept of "Reading for Pleasure", the students could build their own confidence in reading more text in English. It was proved by their comment which stated that they were satisfied with their own effort to finish reading the story. 
Implicitly, based on the students' comments, there were some benefits for them after finishing character analysis in Extensive Reading activity. They could understand the context of sentences in English story, which sometimes used old words (the words are rarely used now). Because of the students' position as the English Department students, it is a must for them to know more vocabulary used in English stories, enabling them experienced how they use the word in a certain context.

- They could increase their self-confidence by finishing the story reading and analysis. This feeling supported them to read more English stories as well as increased their self-confidence, because for some students of non-English Department reading English book is an impossibility.

- They learned new things in interesting way. The things were in the form of vocabulary, context, kinds of expressions, and settings.

- They knew the use of reading fiction text. This kind of text could be used to teach moral value to children and it could be more interested to read rather than non-fiction text. Therefore, in this Extensive Reading activity, all students chose narrative rather than the other genres. Moreover, they could collect more references of English story that would provide them to be more qualified in teaching children.

In addition, the students did not have to pay much attention and remember grammatical patterns to understand the context. As long as they were able to understand the story well, grammar would not be too significant for them to get the point. This case enlightened the students to be more motivated and engaged in reading since grammar had been the difficult thing for any student in learning foreign language.

\section{CONCLUSION}

Analyzing characters in Extensive Reading activity provides several benefits for the students, including learning new vocabulary in enjoyable way, being more critical in reading, having more references of fiction texts, and increasing students' self-confidence. This activity supports English vocabulary learning based on the context, not by looking directly at dictionary. The students' freedom in choosing the material they want to read enables them to practice reading based on their interest, and they can express their ideas through their comments.

Besides improving the students' ability in English mastery, character analysis in Extensive Reading activity can support students' capability and creativity in expressing their ideas. By presenting their analysis on a paper, they get their freedom to draw, write, or add some colors. Writing comment shows their capability in constructing understandable and grammatical sentences.

\section{REFERENCES}

Bamford, J., \& Day, R. R. (2004). Extensive reading activities for language teaching. New York.

Connel, G. (2012). Teaching Character Traits in reader's Workshop. Retrieved from https://www.scholastic.com/teachers/blog-posts/genia-connell/teaching-character-traitsreaders-workshop/ on August 5, 2018

Dickinson, David K., et al. "How reading books fosters language development around the world." Child development research2012 (2012). 
Ferdila, R. (2016). The Use of Extensive Reading in Teaching Reading. Journal of English and Education, 2(2), 68-80.

Hudson, R.F., Mercer, C.D., \& Lane, H.B. (2000). Exploring reading fluency: A paradigmatic overview. Unpublished manuscript, University of Florida, Gainesville.

Krashen, S. D. (2004). The power of reading: Insights from the research: Insights from the research. ABC-CLIO.

Mar, R. A., \&Oatley, K. (2008). The function of fiction is the abstraction and simulation of social experience. Perspectives on psychological science, 3(3), 173-192.

Renandya, W. A. (2007). The power of extensive reading. RELC Journal, 38(2), 133-149.

Richards, J. C., \& Schmidt, R. (2010). Longman dictionary of language teaching and applied linguistics (4th ed.). London: Longman (Pearson Education).

Sofa, E. M. (2018). Islamic Values in Higher Education Students' Communication in Edmodo Learning Platform. EdukasiaIslamika, 3(1), 54-69.

Teaching and Researching Reading. (2002). William Grabe and Fredericka L. Stoller. London: Pearson Education Longman.

www.erfoundation.org 